back to the "Preface." The profundity of thought and range of scholarship that this book reveals makes us doubt "the utter hopelessness [of repaying] at least a fraction of what we receive." A book that can make sense of details that have been dismissed as irrelevant up till now and that can re-position phenomena deemed marginal has not only "repaid" what has been given, but has re-created something of similar value. Indebtedness has thus been handed down to the reader: "feeling the utter hopelessness, yet the unquestionable obligation, of trying to repay at least a fraction of what we receive."

ZSOLT ALMÁSI

\section{The Author Resurrected}

Richard Holmes, Early Visions (London: Harper Collins, 1998). Richard Holmes, Darker Reflections (London: Harper Collins, 1998).

"For in this bleak World of Mutabilities, \& where what is not changed, is chilled, and this winter-time of my own Being, I resemble a Bottle of Brandy in Spitzbergen - a Dream of alcoholic Fire in the centre of a Cake of Ice" ( $D$ p. $550)^{1}$ - wrote Coleridge at the age of fifty-four, and his self-portrait may well indicate not only the reasons why Wordsworth deemed him a "rotten drunkard" and "an absolute nuisance in the Family" ( $D$ p. 214), but also why he

1 References in the text are to pages of Early Visions $(E)$ and Darker Reflections $(D)$. declared that he was "the most wonderful man" he had ever known ( $E$ p. xiii).

Since Coleridge has indeed been accused of misdeeds such as habitual drunkenness, opium addiction, neglect of parental duties and, above all, plagiarism (let us accept this term for the moment), Richard Holmes feels the need to present an interpretation that opposes to the "hostile" ( $E$ p. 376$)$ ones of Hazlitt, Fruman or Lefebure through attempting to answer the "one vital question: what made Coleridge [...] such an extraordinary man, such an extraordinary mind?" ( $E$ p. xiii)

Even if the reader might think that Coleridge has no need for defence given the huge amount of texts written by and on him (e.g. the less "hostile" J. L. Lowes, J. Beer, W. J. Bate or R. Ashton), they would have good reasons for taking his own mocking phrase 
seriously and considering him a true "library cormorant" ( $E$ p. xv.). Holmes's book, without dissipating entirely the views that we may hold about Coleridge, brings the poet alive. The biography, which reads like fiction, acquaints us with a man who was the greatest talker of his age, whose witticisms, puns and inspired digressions left his audience spellbound for hours, but who was also a passionate mountain-climber and a permanent guest at his friends' houses. What seems to me the most revealing aspect of this character, however, is the constant selfanalysis tinged with humour and the sense of the ridiculous in the sublime that intersperse his writings.

Although we are long past the "AGE OF PERSONALITY," the book is supposed to be read like "the most traditional form of popular narrative biography" ( $E$ p. xv.) If we consider this, as well as the fact that instead of focusing on Coleridge the politician or the religious thinker Holmes prefers to lay emphasis on the poet, this work which has had a particularly favourable reception in England, may even be regarded as a response to the recent wave of New Historicist interest in Romantic texts (cf. J. G. McGann on Byron, 1968; P. Foot on Shelley, 1980;
S. Gill on Wordsworth, 1989; E.M. Thompson on Blake, 1993; or A. Motion on Keats, 1997). As a traditional biography, it especially aims to supplement the canonical readings by the reconstruction of Coleridge's childhood, possible sources of inspiration ("the search for sources is itself suggestive of a restless curiosity of the poem's meaning, which does not seem entirely enclosed by the text alone" $-E$ p. 164.) and the identification of "confessional voices" in the writings (D p. 420). But in rejecting "the stock premise that one of the major modern poets hit his true stride in the Ancient Mariner, Christabel, and Kubla Khan,"2 Holmes also challenges the critical tradition and pays especially close attention both to the Conversation Poems, which are fundamental to our notions of Romanticism, and the later poetry, which is indispensable for an understanding of Coleridge. As for the prose writings, he is eminently successful in revealing their verbal artistry through a thorough selection of passages.

Nevertheless, even if the readers accept that the analysis of the poems is as "traditional" as the biography itself, they might feel uneasy when Holmes,

${ }^{2}$ Bate, Coleridge (Columbia U. P., 1987) p. 41. 
on occasion against his own aesthetic judgements, would appear to suggest the superiority of works containing autobiographical elements. Contrasting the Letter to Sara Hutchinson with the final published version of Dejection: $A n$ Ode, he declares: "The Letter draws more directly on Coleridge's true imaginative life. It is richer in, and closer to, those irrepressible sources of imagery which fill his Notebooks and private correspondence: the wind and sunlight over the fells, the moon and stars, the seasonal energy of plants and birds, the life of his children, the longing for love and a happy home. [...] Autobiography, in other words, gives the real authority to the vision of the poem." (E p. 320.) Unsurprisingly, when the formidable issue of plagiarism emerges, Holmes also pleads with a fatherly devotion "the homely touch which is unmistakably his" coming "from the rivers of the Quantocks and the Lake District," as well as the "fundamentally religious drive of the argument, its carefully unfolded imagery, its Platonic overtones, being wholly original and Coleridgean" (on Biographia, Ch. 12, D p. 407-8). Putting aside, for the time being, the questions concerning the concept of plagiarism, we might also ask ourselves whether a source of inspira- tion can be unambiguously defined, that is, whether an image of the "starry Heaven," for instance, linked really back "to the star-gazing he had once shared with his father in the fields of childhood at Ottery St Mary" (on Biographia Ch. 13, D p. 412). Especially when the passage in question begins as follows: "the Religion passes out of the ken of Reason only where the eye of Reason has Reached its own Horizon" and undoubtedly contains some Kantian reminiscences...

Meanwhile, well aware that Coleridge's writings would provide a fertile ground for psychoanalytic criticism, Holmes remains a "moderate" in his treatment of Coleridge's professional failures and miraculous recoveries, his unrequited love for Sara Hutchinson or his turbulent friendship with Wordsworth. His psychological explanations of Coleridge's character are thought-provoking. If opium (or, more precisely, laudanum - a tincture of opium diluted in wine or brandy) was a substitute for love, one would think that his eagerness to write and/or to talk may also have been one. And this latter characteristic might even be due to the poet's constant lamenting over his inability to impose wholeness on his 
materials, since he seemed to fear a lack of mental integrity.

The above-mentioned problems suggest that Coleridge's biographers have a special predicament. In order to create a linear narrative from a teeming mass of notes and fragments, they have the task of making a thorough selection and also find the delicate balance between a textually over-constructed, yet contradictory Romantic self and the 'real man' whose life may slip the "autobiographical project" that has explicitly determined it from the age of twenty-four. In a letter to Thomas Poole dated 6 February, 1797, Coleridge wrote: "As to my Life... you, my best friend! have a right to the narration." Richard Holmes tries to stand firm against the legend maker: he is eager to show his hero through the eyes of the contemporaries (i.e., through the writings of Keats, Hazlitt, the Lambs, John Morgan, Dorothy Wordsworth, and even the report of the secret agent who mistook Coleridge, Wordsworth and Dorothy for spies) while, changing the tone between "satire" and

3 Cf. de Man, 'Autobiography As De-Facement' in The Rhetoric of Romanticism (New York: Columbia U. P., 1984) p. 61.

${ }^{4}$ Quoted by O. Doughty in Perturbed Spirit (London: Fairleigh Dickinson U. P., 1981) p. 9. "passionate elegy" ( $E$ p. 179.), he also regularly contrasts the Notebooks with the public image of Coleridge in order to assess the biographical truth. What he appears to overlook is that Coleridge's own letters and Notebook entries, as well as the letters of his contemporaries, imply an anticipated reader-response. Not willing to engage the autobiographical contract "his Notebooks can never be accepted as a last word on anything" $-E$ p. 91), Holmes still looks with Coleridge and reads the texts as it was 'anticipated.' Thus, even though we are expected to show leniency towards Coleridge for all the misery that he caused his wife, Mrs Coleridge's letters to Thomas Poole are hardly cited, and by the end of the second volume, even Sara Hutchinson's point of view becomes neglected. But the more striking and perhaps the more characteristic instance of Holmes's falling prey to Coleridge's rhetoric of self-justification is when he explains both his hero's weaknesses and, what seems to be more important, his alleged plagiarisms by the poet's opium addiction exclusively.

"- What crime is there scarcely which has not been included in or followed from the one guilt of taking opium? Not to speak of ingratitude to 
my maker for the wasted Talents; of ingratitude to so many friends who have loved me I know not why; of barbarous neglect of my family; [...] when at Box, and both ill - (a vision of Hell to me when think of it!) I have in this one dirty business of Laudanum a hundred times deceived, tricked, nay, actually $\&$ consciously LIED" - wrote Coleridge to John Morgan in 1814 (D p. 357.).

Coleridge, in fact, feared both the verdict of his contemporaries and that of posterity. In Chapter 10 of the Biographia, he alludes to his inability to concentrate his "powers to the realisation of some permanent work" but still agrees to be judged by his "fellow men" by what he has effected, since what he "could have done" is a question of his "own conscience" $(D \mathrm{p}$. 395)... But his own conscience, he hopes, will be disclosed to every one: "After my death [...] a full and unqualified narration of my wretchedness, and of its guilty cause, may be made public" (letter to Josiah Wade, $1814,-D$ p. 366 ). That Holmes sometimes suspends too willingly his disbelief when Coleridge's personality is in question, can be put down to his attempt "to recapture [Coleridge's] fascination as a man and a writer" ( $E$ p.xiii). But I think that the issue of plagiarism and the particular nature of Romantic authorship might have merited a deeper consideration than the one which follows: "For a man of such originality and intellectual brilliance this [plagiarism] is an acute problem in psychological terms, obviously connected with the mendacious habits of his drug addiction" ( $D$ p. 281). The supposition that "drug addicts lie" $(D$ p. 281) may be true, but it does not seem to present very good grounds either for connecting it to the subject of plagiarism, or for entirely disregarding another possible, and not less Coleridgean explanation, unless this latter one contradicts the underlying assumptions of the book. In Chapter 9 of the Biographia, Coleridge deliberately brings up the issue of plagiarism and claims: "I regard truth as a divine ventriloquist: I care not from whose mouth the sounds are supposed to proceed, if only the words are audible and intelligible" ( $D$ p. 402$)$. I think that rather than being (mis)taken for mere self-defence, the above statement together with the fragments, openended works, abstruse writings, Conversation Poems, written and oral monologues, the glosses and the prefaces which were added to the poems after 1800 - could be considered as a part of 
Romantic irony stemming from that very German philosophy that Coleridge also incorporated into his works. As a matter of fact, we do not even have to employ a recently defined paradigm in analysing Coleridge's writings (see the works of Mellor, Wheeler or Garber), if we take into account that the ten months he spent in Germany (from September 1798 until July 1799) conspicuously coincides with the era of the periodical Athenaeum, which was the most important phase in the development of a critical theory of irony as defined, first and foremost, by Friedrich Schlegel. Hence, I would think that the arguments which seek to defend Coleridge against the charge of plagiarism should emphasise not the curse of being "an opium eater," but the fact that Coleridge's reading of the Schlegel brothers, Novalis, Solger, Tieck and Richter did not only mean an acquaintance with their "dynamic" philosophy, but also, among others, with the dream of a Symphilosophy and with the rejection of the notions of unity and originality in favour of mixtures, shared authorships, plagiarisms and fragments. Alternatively, even if we accept opium addiction as a primary cause of his "literary kleptomania" ( $E$ p. 43$)$, it would not have been an exaggeration to remark that Coleridge's most indispensable form of plagiarism was perhaps the act of plagiarising itself. In addition, the collaborative relationship between Coleridge and Southey or between Coleridge and Wordsworth (see, for instance, Wordsworth's Preface to the first edition of the Lyrical Ballads where no indication as to the authorship of the several poems is offered) could already "call attention to a possible weak link in the 'genial' conception of authorship per se."

It must be admitted, however, that the choice of the Romantic ideology of the original, authentic poet diffusing "a tone and spirit of unity"(Biographia, Ch. 14.) over that of the "divine ventriloquist" with his "palimpsest tablet" of memory (Prefatory Note to The Wanderings of Cain, 1828) might be concomitant with the genre of "traditional" biography.

I should add to all this that Holmes's insistence upon originality eventually drove me to the other extreme, and I began to see "influence" where he found "genuineness." An instance of this was the footnote in which he praises "Coleridge's subtle, bifurcating bequest of ideas to

A. Hickley, "Coleridge, Southey, and Co.," in Studies in Romanticism 3 (1998) p. 306. 
posterity," citing the following "seminal concept": "Every man is born an Aristotelian, or a Platonist.... They are the two classes of men, besides which it is impossible to conceive a third." Apart from the fact that this generalisation does not seem to me seminal to Western culture, nor its impact on "modern neurological theory which now seems to find the same [?] division between the left and right hemispheres of the brain" ( $D$ p. 492) very considerable, it shows a striking similarity to Fichte's view that the sort of philosophy which a man chooses depends on the sor bf man that he is. According to Fichte, there are only two kinds of philosophy: dogmatism, absolutizing the object (Fichte's Spinoza - Coleridge's Aristotle) and criticism, absolutizing the subject (Fichte himself - Coleridge's Plato).

Besides the above example, Holmes's footnotes, "which initiate another level of speculation [...] reflecting on the action as it develops" ( $E$ p. xvi), are informative: they give account of various subjects such as Coleridge's financial situation, the contemporary state of knowledge about opium addiction or the English translations of German authors.

One of the most important merits of the book is the detail it gives on the 19th century reception of Coleridge's writings, lectures and the only staged play, Remorse, which ended up being the greatest success of his life. To mention a few of the colourful details: "There is something disgusting at the bottom of his subject" (Hazlitt on Christabel, D p. 434.); "unintelligible" (Hazlitt on the theory of the Imagination, $D$ p. 453 .); much "vicious affectation of phraseology" (Coleridge himself on the Religious Musings, $E$ p. 115); "Coleridge said in the advertisement he would speak about the Nurse in Romeo and Juliet, and so he is delivering the lecture in the character of the Nurse" (Charles Lamb whispering to Crabb Robinson during Coleridge's half an hour digression on contemporary politics in the middle of a lecture on Shakespeare, $D$ p. 273.).

Holmes's monumental biography presents a huge amount of data within a carefully structured and compelling story. Indeed, it realises Coleridge's hope that a later generation might turn his life, that he believed was "little more than a far-stretched Series of Et Ceteras," into a cohesive, linear narrative.

ANDREA TIMÁR 